\title{
PENERAPAN PRESIDENTIAL THRESHOLD PASCA PUTUSAN MAHKAMAH KONSTITUSI NOMOR 14/PUU-XI/2013
}

\author{
Liberthin Palullungan, Trifonia Sartin Ribo \\ Universitas Kristen Indonesia Paulus, Liberthin@ukipaulus.ac.id
}

\begin{abstract}
Abstrak
Indonesia adalah negara yang menerapkan secara bersama-sama antara sistem presidensial dan sistem multipartai. Pelaksanaan pemilihan umum sudah diatur dalam Undang-Undang Negara Republik Indonesia Tahun 1945. Presidential threshold merupakan suatu konsep yang digunakan dalam pengusulan calon Presiden dan Wakil Presiden. Pengusulan dilakukan oeh partai politik atau gabungaan partai politik oleh peserta pemilihan umum. Artikel ini menganalisis penerapan Presidensitial threshold pasca putusan Mahkamah Konstitusi Nomor 114/PUU-XI/2013. Tujuan penulisan ini adaah untuk mengetahui Penerapan Presidensitial threshold pasca putusan Mahkamah konstitusi Nomor 14/PUU-XI/013, dan menegtahui dampak putusan Mahkamah Konstitusi nomor 14/PUU-XI/2013 terhadap partai politik. Adapun metode penelitian yang digunakan adalah metode penelitian normatif kualitatif dan konseptual. Berdasarkan artikel ini diketahui bahwa penerapan presidential threshold dimana partai politik harus memperoleh kursi 20\% dari jumlah kursi DPR atau $25 \%$ dari suara sah secara nasional pada pemilihan DPR sebelumnya, sehingga membuat partai baru atau kecil tidak akan dapat mengusulkan Presiden dan Wakil Presiden sendiri, tetapi partai dapat melakukan koalisi.
\end{abstract}

Kata Kunci : Presidential Threshold; Putusan Mahkamah Konstitusi

\begin{abstract}
Indonesia is a country that implements a presidential system and a multi-party system jointly. The implementation of general elections has been regulated in the 1945 Constitution of the Republic of Indonesia. The presidential threshold is a concept used in proposing candidates for President and Vice President. Proposals are made by political parties or joining political parties by general election participants. This article analyzes the application of the presidential threshold after the Constitutional Court decision Number 114 / PUU-XI / 2013. The purpose of this writing is to determine the application of the Presidensitial threshold after the Constitutional Court decision Number 14 / PUUXI / 013, and to determine the impact of the Constitutional Court decision number 14 / PUU-XI / 2013 on political parties. The research method used is qualitative and conceptual normative research methods. Based on this article, it is known that the application of the presidential threshold in which political parties must obtain seats $20 \%$ of the number of seats in the DPR or $25 \%$ of the valid votes nationally in the previous DPR elections, so that making new or small parties will not be able to nominate the President and Vice President themselves, but parties can form a coalition.

Keywords : Presidential Treshold; Constitusional Court Decision.
\end{abstract}

\section{Pendahuluan}

Pemilihan Umum (Pemilu) adalah alat yang sangat penting dalam negara demokrasi dengan adanya sistem perwakilan. Pemilu merupakan wujud yang nyata dari demokrasi prosedural. Indonesia sebagai negara hukum dengan pemerintahan yang demokratis menguji pemilu sebagai patokan penting, yang mana harus 
diselenggarakan secara demokratis. Indonesia telah mengatur perihal pelaksanaan pemilu yang tercantum dalam UUD NKRI Tahun 1945.

Pemilu adalah lembaga terpenting agar terpenuhinya tiga prinsip pokok demkorasi dalam pemerintahan yang berbentuk Republik, yaitu kedaulatan rakyat, keabsahan pemerintahan dan pergantian pemerintahan secara teratur. Pemilu sebagai perwujudan demokrasi dianggap sebagai saran atau prosedur yang ideal dalam rangka proses peralihan kekuasaan secara tertib dan damai. Dalam penyelenggaran pemilu, maka harapkan proses peralihan kekuasaan dalam suatu negara akan dapat berjalan dengan baik dan tertib. Kegiataan pemilu merupakan sebuah sarana untuk menyalurkan hak asasi warga negara yang prinsipil. Oleh karean itu, dalam rangka pelaksanaan hak asasi warga negara menjadi suatu keharusan bagi pemerintah untuk menjamin terselenggarnya pemilu dengan jadwal ketatanegaraan yang ditentukan. ${ }^{1}$

Berdasarkan ketentuan UUD NKRI tahun 1945, yang termasuk dalam pemilu adalah pemilihan anggota dewan Perwakilan Rakyat (DPR), Dewan Perwakilan Daerah (DPD), dan Dewan Perwakilan rakyat Daerah (DPRD), serta pemilihan Presiden dan Wakil Presiden. ${ }^{2}$ Namun dalam praktiknya selama ini, pemilihan anggota DPR,DPD, dan DPRD ditempatkan secara terpisah dengan pemilhan Presiden dan Wakil pesiden dalam rezim pemilu legislatif. Sedangkan pemilhan Presiden dan Wakil Presiden ditempatkan dan diselenggarakan secara tersendiri dalam rezim pemilihan Presiden dan Wakil Presiden.

Pentingnya model penyelenggaraan dalam pemillihan umum maka diajukan permohonan gugatan uji materi atas Undang-Undang Nomor 42 tahun 2008 Tentang pemilihan umum Presiden dan Wakil Presiden. Mahkamah Konstitusi dalam putusannya menyampaikan bahwa peneyelenggaraan pemilihan umum legislatif dan pemilihan umum Presiden dan Wakil Presiden dilaksanakan secara bersama-sama yang berlaku pada pemilu 2019 dan sampai seterusnya. ${ }^{3}$

Adapun untuk pencalonan Presiden dan Wakil Presiden diatur dalam Pasal 6A ayat (2) UUD NKRI 1945. Maka sistem Presidential threshold menjadi tidak memiliki relevan lagi atau sudah kehilagan urgensinya dengan adanya pemilu serentak berdasarkan Putusan MK Nomor 14/PUU-XI/2013. ${ }^{4}$ Tetapi hal tersebut secara tidak langsung menyatakan bahwa pemerintahan masih akan memberlakukan Presidential threshold dalam pemilu serentak. Sehingga jika melihat ketentuan tersebut akan menimbulkan berbagai pro dan kontra dari partai-partai politik karena tidak semua

\footnotetext{
${ }^{1}$ Jimly Asshiddiqie, 2010, Pengantar Hukum Tata Negara, PT. Raja Grafindo Uatama, Jakarta, hal. 416.

2Pasal 6A ayat (1) dan (2) UUD Negara RI tahun 1945

${ }^{3}$ Lihat Putusan Mahkamah Konstitusi No. 14/PUU-XI/2013 dalam perkara pengujian Undang-Undang No. 42 Tahun 2008 tentang Pemilihan Umum Presiden dan Wakil Presiden terhadap UUD NKRI Tahun.

${ }^{4}$ Lytha Dayanara, 2017, Relevasi Sistem Presidential Treshold dalam Model Penyelenggaraan Pemilu Serentak, Skripsi, Universitas Negeri Semarang, hal. 3.
} 
partai politik akan mendukung gagaasan pemerintahan untuk memberlakukan presidential threshold berdasarkan hasil pemilihan legislatif. 5

Tidak dapat kita pungkiri bahwa kemunculan partai politik yang beragam merupakan dampak dari berbagai banyak budaya politik masyarakat Indonesia. Kehadiran partai politik dapat membuat efektif dan efisien karena sangat diharapkan mampu mengurangi konflik yang bermunculan ketika pesta demokrasi berlangsung. Serta, partai politik juga dapat perlu membuat persiapan yang matang dalam memilih kadernya. Sehingga dengan cara ini, partai politik diharapkan mampu melahirkan calon pemimpin yang berintegritas, mampu mengabdi bagi bangsa dan negara.

Berdasarkan latar belakang diatas, maka penulis menemukan beberapa masalah, adapun rumusan masalah tersebut, yaitu Bagaimanakah Penerapan Presidential Threshold pasca Putusan Mahkamah Konstitusi Nomor 14/PUUXI/2013, dan ppakah dampak Putusan Mahkamah Konstitusi Nomot 14/PUUXI/2013 terhadap Partai Politik?

\section{Metode}

Penulisan artikel ini menggunakan metode penelitian hukum dengan pendekatan Yuridis normetif dengan mengacu pada norma hukum nasional. Data yang digunakan dalam artikel ini adalah sekunder berupa bahan primer yaitu Putusan MK No. 14/PUU-XI/2013, dan bahan sekunder yaitu berupa buku, jurnal, dan artikel yang terkait. Anlisis data dalam artikel ini menggunakan analisis kualitatif dengan mendeskripsikan fakta-fakta yang ada, kemudian dilakukan analisis berdasarkan norma-norma hukum dan teori yang ada.

\section{Konsep Presidential Threshold.}

Presidential Threshold terdiri dari dua suku kata yang bersal dari bahasa Inggris yaitu Presidential dan Threshold. Tetapi secara etimologi kata presidential memiliki makna mengenai Presiden, ${ }^{6}$ dan kata threshold memiliki makna ambang pintu. ${ }^{7}$ Jadi Presidential Threshold adalah tingkat minimal dukungan yang harus diperoleh oleh partai poltik atau gabungan partai politik untuk dapat mengusungkaan bakal calon Presiden dan Wakil Presiden. Ketentuan pengaturan Presidential Threshold dalam sistem pemilihan umum Presiden dan Wakil Presiden untuk pertama kali dilakukan secara langsung pada tahun 2004.

Pengertian Presidential Threshold adalah pengaturan tingkat ambang batas dukungan dari DPR, baik dalam bentuk jumlah perolehan suara (ballot) atau jumlah perolehan kursi (seat) yang harus diperoleh partai poltik peserta pemilihan umum

\footnotetext{
${ }^{5}$ Ibid., hal. 4.

${ }^{6} J o h n$ M. Echols dan Hassan Shadily, 2005, Kamus Inggris-Indonesia, PT.Gramedia Pustaka Utama, Jakarta, hal. 445 .

${ }^{7}$ Ibid., hal. 589.
} 
agar dapat mencalonkan Presiden dan Wakil Presiden dari partai politik tersebut dan/atau gabungan partai politik. ${ }^{8}$

Sistem Presidential Threshold pada awalnya digunakan untuk melihat tingkat persaingan/kompetisi partai untuk dapat menduduki kursi di derah pemilihan didalam sistem pemilu proposional. Besaran daerah pemilihan dan perolehan kursi partai dengan metode kuota, jika kecil presentasi perolehan suara yang didapat untuk mendapat kursi, maka sangat kecil daerah pemilihan, dan sebaliknya semakin besar persentase perolehan suara yang didapat maka semakin besar mendapatkan kursi.

Presidential Threshold adalah ketentuan tambahan mengenai pengaturan tentang syarat pencalonan Presiden dan Wakil Presiden dalam Pasal 6A ayat (2) yang menyataka bahwa "Pasangan calon Presiden dan Wakil Presiden diusulkan oleh partai politik dan/atau gabungan partai politik peserta pemilihan umum sebelum pelaksanaan pemiliham umum".

\section{Penerapan Presidential Threshold Pasca Putusan Mahkamah Konstitusi Nomor 14/PUU-XI/2013}

Selama ini pemilihan Presiden dan Wakil Presiden dilakukan Secara terpisah dengan pemilihan Legislatif. Effendi Gazali menganggap hal ini tidak selaras dengan ketentuan yang ada di dalam Undang-undang Dasar Negara Republik Indonesia Tahun 1945. Oleh karena itu, permohonan pengujian materi yang diajukan oleh Dosen Universitas Indonesia (UI) Effendi Ghazali, dan Termohon Pemerintah dan DPR yang membuat Undang-Undang Nomor 42 Tahun 2008 tentang Pemilihan Umum Presiden dan Wakil Presiden kepada Mahkamah Konstitusi pada tanggal 10 Januari 2013, yang pada tanggal 22 Januari 2013 permohonan tersebut diterima secara resmi diterima. Dalam putusan tersebut, MK menyatakan pemilihan umum presiden dan wakil presiden maupun pemilihan umum legislatif dilakukan serentak.

Effendi Ghazali sebagai pemohon bermaksud melakukan pengujian kembali pasal tersebut dengan alasan konstitusional dengan kerugian yang berbeda, adapun dalil-dalil dari pemohon kepada Mahkamah Konstitusi sebagai berikut: ${ }^{9}$

1. Dari segi efisiensi penyelenggaraan pemilu. Bahwa terdapat pemborosan APBN dan APBD berkisar antara 5 hingga 10 Trilyun Rupiah dalm hal Pemilu Presiden dan Wakil Presiden terpisah dengan Pemilu Anggota DPR, DPRD, dan DPD; atau sampai berkisar 20 hingga 26 Trilyun.

2. Hak warga negara untuk memilih secara efisien terkait penggunaan waktu, energi, dan biaya. Warga negara seharusnya lebih terjamin hak pilihnya jika pemilihan umum diselenggarakan secara serentak.

3. Tidak ditegakkan atau diperkuatnya sistem presidensial sesungguhnya.

\footnotetext{
${ }^{8}$ Sigit Pamungkas, 2009, Perihal Pemilu, Laboratorium jurusan Ilmu Pemerintahan dan jurusan IImu Pemerintahan Fisipol UGM, Yogyakarta, hal. 19.

${ }^{9}$ Ibid., hal. 6.
} 
Pemohon memohon kepada Mahkamah Konstitusi untuk menguji Pasal 3 ayat (5), Pasal 9, Pasal 12 ayat (1) dan (2), Pasal 14 ayat (2) dan Pasal 112 Undang-Undang Nomor 42 Tahun 2008 tentang Pemilihan Umum Presiden dan Wakil Presiden terhadap Pasal 1 ayat (2), Pasal 4 atar (1), Pasal 6A ayat (1) dan ayat (2), Pasal 22E ayat (1) dan ayat (2), Pasal 27 ayat (1), Pasal 28D ayat (1), Pasal 28D ayat (1), Pasal 28H ayat (1), dan Pasal 33 ayat (4) Undang-Undang Dasar Negara Republik Indonesia Tahun 1945.10

Bahwa berdasarkan dalil-dalil hukum yang telah diuraikan oleh pemohon, maka pemohon meminta agar Mahkamah Konstitusi Republik Indonesia dapat mengabulkan dan menyatakan bahwa Pasal-Pasal tersebut bertentangan dengan Undang-Undang Dasar Negara Republik Indonesia serta tidak mempunyai kekuatan hukum yang mengikat.

Mahkamah Konstitusi menimbang bahwa dalam menentukan konstitusionalitas penyelenggaraan pemilihan umum Presiden dan Wakil Presiden setelah Pemilihan Umum anggota DPR, DPD, DPRD harus memperhatiakan 3 (tiga) pertimbangan pokok. Ketiga pertimbangan pokok itu adalah adanya kaitan antara sistem pemilihan dan pilihan sistem pemerintahan presidensial, original intent dari pembentukan Undang-Undang Dasar Tahun 1945, efektivitas dan efesiensi penyelenggaraan pemilihan umum, dan hak warga negara untuk memilih secara cerdas. ${ }^{11}$

1. Kaitan antara sistem pemilihan dan pilihan sistem pemerintahan presidensial, menurut Mahkamah Konstitusi penyelenggara pemilihan umum Presiden dan Wakil Presiden harus dikaitkan dengan rancang bangun sistem -sistem pemerintahan presidensial. Posisi Presiden dan Wakil Presiden dalam hubungannya dengan DPR adalah sejajar dengan prinsip hubungan yang saling mengawasi dan mengimbangi (check and balances). Sesuai dengan Ketentuan UUD NKRI 1945 dapat disimpulkan juga bahwa pada satu sisi, sistem pemerintahan Indonesia menempatkan partai politik dalam posisi penting dan strategis, yaitu Presiden memerlukan dukungan partai politik yang memiliki anggota di DPR untuk efektivitas penyelenggaraan pemerintahannya dan pada sisi lain menempatkan rakyat dalam posisi menentukan legitimasi seorang Presiden. Dengan demikian, efektivitas penyelenggaraan pemerintahan oleh Presiden dan Wakil Presiden sangat berkaitan dengan dua dukungan, yaitu partai politik satu sisi dan dukungan rakyat pada satu sisi yang lain. ${ }^{12}$

2. Original intent dari pembentukan Undang-Undang dasar Negara Republik Indonesia Tahun 1945 dan Penafsiran sistematik, bahwa penyelenggaraan pemilihan Presiden dan Wakil Presiden adalah dilakukan serentak dengan

\footnotetext{
${ }^{10}$ lbid, hal. 6.

${ }^{11}$ Rubian Arviani, Op.Cit. ,hal. 6.

${ }^{12}$ Ibid., hal. 7.
} 
pemilihan Legislatif. Dari sudut pandang original intent dari penyusun perubahan UUD NKRI 1945 telah terdapat gambaran visioner mengenai mekanisme penyelenggaraan pemilihan Presiden dan Wakil Presiden, bahwa pemilihan Presiden dan Wakil Presiden diselenggarakan secara bersamaan dengan pemilihan legislatif. Selain itu, dengan menggunakan penafsiran sistematis akan ketentuan Pasal 6A ayat (2) UUD NKRI 1945 yang menyatakan bahwa “ pasangan calon Presiden dan Wakil Presiden diusulkan oleh partai politik atau gabungan partai politik peserta pemilihan umum sebelum pelaksanaan pemilihan umum" dikaitkan dengan Pasal 22E ayat (2) UUD NKRI 1945 yang menyatakan bahwa "pemilihan umum diselenggarakan untuk memilih anggota DPR,DPD,DPRD", adalah tidak mungkin yang dimaksud "Sebelum pemilihan umum" dalam Pasal 6A ayat (2) UUD NKRI 1945 adalah sebelum pemilihan Presiden dan Wakil Presiden, karena jika frasa "sebelum pemilihan umum" dimaknai sebelum pemilihan Presiden dan Wakil Presiden , maka frasa "sebelum pemilihan umum" tersebut menjadi tidak diperlukan, karena calon Presiden dengan sendirinya memang harus diajukan sebelum pemilihan Presiden. ${ }^{13}$

3. Efisiensi anggaran yang dikeluarkan dalam penyelenggaraan pemilihan umum. Penyelenggaraan pemilihan Presiden dan Wakil Presiden dan Pemilihan umum legislatif secara serentak memang akan lebih efisien, sehingga pembiayaan penyelenggaraan lebih menghemat uang negara yang berasal dari pembayaran pajak dan hasil eksploitasi sumber daya alam serta sumber daya ekonomi lainnya. Hak warga negara untuk memilih secara cerdas pada pemilihan umum serentak ini terkait dengan hak warga negara untuk membangun check and balances dari pemerintahan presidensial dengan keyakinnya sendiri. Untuk itu warga negara dapat mempertimbangkan sendiri mengenai penggunaan pilihan untuk memilih anggota DPR dan DPRD yang berasal dari partai yang sama dengan calon Presiden dan Wakil Presiden. ${ }^{14}$

Adapun amar putusan megadili, menyatakan :15

1. Mengabulkan permohonan termohon pasal 3 ayat (5), Pasal 12 ayat (1) dan ayat (2), Pasal 14 ayat (2) dan Pasal 112 Undang-Undang Nomor 42 Tahun 2008 tentang pemilihan umum Presiden dan Wakil Presiden yang tidak sesuai dengan UUD NKRI 1945.

2. Amar putusan pada angka satu berlaku untuk penyelenggaraan pemilihan umum tahun 2019 dan pemilihan umum selanjutnya.

Mahkamah Konstitusi pada akhirnya dalam mengeluarkan putusan Nomor 14/PUU-XI/2013 dengan mengabulkan sebagian dari yang dimohonkan oleh pemohon. Tetapi ada salah satu pasal yang tidak dikabulkan oleh Mahkamah

\footnotetext{
${ }^{13}$ lbid., hal. 8.

${ }^{14}$ Ibid., hal. 8.

${ }^{15}$ Lihat Putusan Mahkamah Konstitusi Nomor 14/PUU-XI/2013., Op.Cit.
} 
Konstitusi yaitu Pasal 9 terkait presidential threshold, Mahkamah berpendapat “ Adapun mengenai pengujian konstitusionalitas Pasal 9 Undang-Undang 42 tahun 2008, Mahkamah mempertimbangkan bahwa didalam penyelenggaraan pemilihan Presiden dan Pemilihan Umum anggota lembaga Perwakilan dalam pemilhan umum secara serentak maka ketentuan pasal persyaratan perolehan suara partai politik sebagai syarat untuk mengajukan pasangan calon Presiden dan Wakil Presiden merupakan kewenangan pembentukan Undang-Undang dengan tetap mendasarkan pada ketentuan UUD NKRI 1945". 16

Implikasi putusan Mahkamah Konstitusi Nomor 14/PUU-XI/2013, Mahkamah telah menafsirkan pengertian pemilihan umum yang ada didalam UUD NKRI 1945. Pada pertimbangannya, Mahkamah memberikan penafsiran dari Pasal 22E ayat (2) UUD NKRI 1945 yang menyatakan bahwa pemilihan umum Presiden dan Wakil Presiden dilaksanakan secara bersamaan dengam pemilihan umum untuk memilih anggota legislatif dengan tetap memberlakukan syarat pencalonan Presiden dan Wakil Presiden. Penerapan Presidential threshold menurut Pasal 9 UndangUndang Nomor 42 Tahun 2008 yang menyatakan, “ Pasangan Calon diusulkan oleh partai politik atau gabungan partai politik peserta pemilu yang memenuhi persyaratan perolehan kursi paling sedikit 20\% (dua puluh persen) dari jumlah kursi DPR atau perolehan kursi paling sedikit 25\% (dua puluh lima persen) dari suara sah nasional dalam pemilu anggota DPR, sebelum pelaksanaan Pemilu Presiden dan Wakil Presiden". ${ }^{17}$

\section{Dampak Putusan Mahkamah Konstitusi Nomor 14/PUU-XI/2013 terhadap Partai Politik}

Dampak negatif dengan digunakannya putusan Mahkamah Konstitusi Nomor 14/PUU-XI/2013 dengan sistem Presidential thrsehold tersebut,yaitu :

1. Partai politik yang baru tidak dapat mencalonkan Presiden dan Wakil Presiden sendiri terutama bagi partai-partai kecil tanpa berkoalisi dengan partai lainnya sampai bisa memenuhi syarat presidential threshold 20-25\% suara. Partai politik baru juga tidak dapat mencalonkan Presiden dan Wakil Presiden, karena adanya acuan dalam penetapan ambang batas $20-25 \%$ suara tersebut berasal dari pemilu sebelumnya.

2. Kebigungan pemilih terhadap jumlah calon presiden.

3. Menghalangi peluang setiap warga negara dalam mencalonkan diri menjadi Presiden dan Wakil Presiden melalui partai-partai tertentu.

Dampak Positif diterapkannya sistem Presidential threshold menurut putusan Mahkamah Konstitusi Nomor 14/PUU-XI/2013, yaitu:

\footnotetext{
${ }^{16}$ Veni Fendabi, 2019, Penerapan Ambang batas Presidensial (Presidential Threshold) sebagai Kebijakan Hukum terbuka dalam Pemilihan Umum Di Indonesia (Analisis Putusan Mahkamah Konstitusi Nomor 53/PUU-XV/2017), Universitas Islam Negeri FH, Jakarta, hal. 46

${ }^{17}$ Sigit Pamungkas., Loc.Cit. hal. 19.
} 
1. Dapat mempertegas sistem Presidensial yang dianut, secara dapat mengurangi praktek politik transaksional, dan pragmatis antara eksekutif dan legislatif. Karena sudah dari awal partai politik atau gabungan partai politik sudah menguatkan barisan koalisinya, agar terpilih calon Presiden dan Wakil Presiden yang diusungnya. Sehingga Presiden juga tidak menguras tenaga membangun koalisi jika terpilih, dengan membagun koalisis yang ideal yang dapat mengatur dan mendukung kebijakan eksekutif pada titik ini

2. Penyelenggaraan Pemilihan Umum Serentak legisltaif dan eksekutif bisa dikonkret dan akan mengehebat uang negara yaang tidak sedikit.

3. Pemilihan Umum yang dilakukan hanya satu kali dalam satu periode, secara otomatis akan mengahalangi niat dan politik para kerabat, untuk mengikutsertakan anggota keluarganya mengganti kedudukannya yang dijabati saat itu. Alasannya tidak mungkin menggiring anggota keluarganya masuk kedalam lingkaran kekuasaan dengan posisi yang dia miliki, jika pada waktu mencalonkan dirinya sebagai pejabat eksekutif

terkendala oleh batsan waktu.

\section{Kesimpulan}

Penerapan presidential threshold pasca Putusan Mahkamah Konstitusi Nomor 14/PUU-XI/ / 2013 berimplikasi pada aturan Pemilihan Umum Serentak yang tetap mengacu pada Pasal 9 Undang-Undang Nomor 42 tahun 2008 Tentang Pemilihan Umum Presiden dan Wakil Presiden yang tetap memberlakukan syarat pencalonan Presiden dan Wakil Presiden yang dapat diusulkan oleh partai politik atau gabungan partai politik pesrta pemilu yang telah memenuhi persyaratan perolehan kursi paling sedikit 20\% (dua puluh persen) dari jumlah kursi di DPR atau memperoleh 25\% (dua puluh lima persen) dari suara sah secara nasional pada pemilihan umum DPR sebelumnya. Keberadaan putusan Mahkamah Konstitusi dengan sistem presidential threshold secara tidak langsung menutup ruang bagi partai politik baru untuk mencalonkan Presiden dan Wakil Presiden berdasarkan aspirasi konstituen dari masing-masing partai politik tersebut.

\section{REFERENSI}

Asshiddiqie, Jimly. Pengantar Hukum Tata Negara. Jakarta: PT. Raja Grafindo Utama, 2010.

Arviani, Rubian. “Analisis Putusan Mahkamah Konstitusi nomro 14/PUU-XI/2013 Berkaitan Dengan Pemilihan Umum Serentak Di Indonesia". Vol. 5, Nomor 4, Tahun 2016.

John M. Echols dan Hassan Shadily, Kamus Inggris-Indonesia . Jakarta: PT.Gramedia Pustaka Utama, 2005. 
Sigit Pamungkas, Perihal Pemilu .Yogyakarta: Laboratorium jurusan Ilmu Pemerintahan dan jurusan Ilmu Pemerintahan Fisipol UGM, 2009.

Lytha Dayanara, Skripsi : “Relevasi Sistem Presidential Treshold dalam Model Penyelenggaraan Pemilu Serentak" .Semarang: UNNES, 2107.

Veni Fendabi, Skripsi : "Penerapan Ambang batas Presidensial (Presidential Threshold) sebagai Kebijakan Hukum terbuka dalam Pemilihan UmumDi Indonesia (Analisis Putusan Mahkamah Konstitusi Nomor 53/PUU-XV/2017). Jakarta : Universitas Islam Negeri FH, 2019. 